\title{
LABOR LAW: SEVENTH CIRGUIT HOLDS AUTHORIZATION CARDS EXEMPT FROM THE ONE-YEAR BAR OF SEGTION 9 (c) (3)
}

$\mathrm{I}_{\mathrm{N}}$ Conren $v . N L R B,{ }^{1}$ the United States Court of Appeals for the Seventh Circuit held that an employer could not successfully invoke the election year bar of section 9 (c) (3) of the NLRA ${ }^{2}$ and refuse to bargain with a union which had presented within the election year authorization cards signed by a majority of his employees. After an organizational campaign carried on by both the Retail Clerks and the Teamsters Unions, the NLRB conducted an election on June 7, 1963, in which the majority of employees voted for no union. ${ }^{3}$ The validity of this election was not challenged. On March 19, 1964, the Retail Clerks demanded recognition as the bargaining representative for all Conren employees since it then possessed authorization cards signed by thirty-two of the fifty-three employees. The employer rejected the union's demand, contending that by virtue of section 9 (c) (3) of the NLRA he was not obliged to bargain with anyone for. one year after the June election. ${ }^{4}$ The union then filed unfair labor practice charges with the NLRB based on the employer's refusal to bargain as well as on other conduct of the employer subsequent to the election. The Board found that Conren had violated sections 8 (a) (1), (2), (3), and (5) of the NLRA and accordingly ordered the firm to bargain with the Retail Clerks. ${ }^{5}$

Under the NLRA, a duty to bargain arises whenever a bargaining representative is "designated or selected for the purposes of collective bargaining by the majority of the employees ...." Although it is arguable that in passing the Taft-Hartley Act Congress intended that an election should be the exclusive means by which a bargaining representative could be chosen, ${ }^{7}$ the courts have interpreted the "designated or selected" language of section 9 (a) disjunctively and therefore as evincing congressional permission that procedures

1368 F.2d 173 (7th Cir. 1966), cert, denied, 35 U.S.L. WEEK 3328, 3330 (U.S. March 20, 1967) (No. 1029).

2 Added by 61 Stat. 144 (1947), as amended, 29 U.S.C. $\$ 159$ (c) (3) (1964).

${ }^{3}$ Conren, Inc., 61 L.R.R.M. 1090, 1091 (1966).

1 Id. at 1094.

Id. at 1096.

- National Labor Relations Act $\$ 9$ (a), 61'Stat. 143 (1947), 29 U.S.C. $\$ 159$ (a) (1964).

' See note 34 infra and accompanying text. 
less formal than elections may also be utilized. ${ }^{8}$ Thus, the use of authorization cards has become firmly established as an allowable medium for the selection of a bargaining representative. ${ }^{9}$ Nevertheless, both the Board and commentators have expressed a preference for the secret ballot election because of the privacy and independence which it affords to the voter. ${ }^{10}$ Indeed, the Board has expended much effort striving for "laboratory conditions"11 to insure the integrity of the electoral process. ${ }^{12}$ There is not, however, an absolute right to an election; ${ }^{13}$ and if the desires of the employee majority are clearly expressed through more informal means such as authorization cards, then the employer has a duty to bargain with the selected representative. ${ }^{14}$ Recent Board decisions facilitating the use of $\operatorname{cards}^{15}$ have increased union reliance on this device in seeking the status of bargaining representative. ${ }^{16}$

While authorization cards are a substitute for an election, they are not accorded the same conclusive effect as an election. For example, under the NLRA, certification is granted only after a Board election; ${ }^{17}$ likewise the certification year bar of section 9 (c) (3) is not effective when recognition is gained through cards. ${ }^{18}$ Moreover,

\footnotetext{
${ }^{8}$ See Frank Bros. Co. v. NLRB, 321 U.S. 702 (1944); cf. United Mine Workers v. Arkansas Oak Flooring Co., 351 U.S. 62 (1956). See generally Comment, Union Authorization Cards, 75 YaLe L.J. 805, 821 (1966).

'See, e.g., NLRB v. Gotham Shoe Mfg. Co., 359 F.2d 684 (2d Cir. 1966); Lewis, The Use and Abuse of Authorization Cards in Determining a Union Majority, 16 LAB. L.J. 434 (1965); Comment, 75 YaLE L.J. 805 (1966).

${ }^{10}$ Aaron Bros., 158 N.L.R.B. No. 108 (1966) (dictum); see Lewis, supra note 9; Comment, 75 YALE L.J. 805 (1966).

11 General Shoe Corp., 77 N.L.R.B. 124, 127 (1948); 368 F.2d at 176-77 (dissenting opinion).

12 See, e.g., Hollywood Ceramics Co., 140 N.L.R.B. 221 (1962) (misrepresentation in election propaganda); Sewell Mfg. Co., 138 N.L.R.B. 66 (1962) (improper appeal to racial prejudice); Dal-Tex Optical Co., 137 N.L.R.B. 1782 (1962) (employer threats prior to election). See generally Bok, The Regulation of Campaigu Tactics in Representation Elections Under the National Labor Relations Act, 78 HARV. L. REv. 38 (1964).

${ }^{13}$ NLRB v. Trimfit of California, Inc., 211 F.2d 206, 209 (9th Cir. 1954). But see note 34 infra and accompanying text.

It See United Mine Workers v. Arkansas Oak Flooring Co., 351 U.S. 62, 74 (1956). But see note 34 infra and accompanying text.

${ }^{15}$ Bernel Foam Prods. Co., I46 N.L.R.B. 1277 (1964); see Excelsior Underwear, Inc. and Saluda Knitting, Inc., 156 NL.R.B. No. 111 (1966); Randall, The NLRB's New Policy on Bargaining Orders Following Representation Elections, 52 A.B.A.J. 1038 (1966); Shuman, Requiring a Union to Demonstrate Its Majority Status By Means of Election Becomes Riskier, 16 LAB. L.J. 426 (1965).

${ }^{10}$ See Note, 33 U. CHI. L. REv. 387, 388 nn.7-11 (1966).

${ }^{17}$ National Labor Relations Act $\$ \S 9$ (c) (1) (B), (e), 61 Stat. 144 (1947), 29 U.S.C. $\$ \S 159$ (c) (1) (B), (e) (1964).

${ }^{18}$ National Waste Material Corp., 93 N.L.R.B. 477 (1951).
} 
the protections of sections 8 (b) (4) (B) and (C) of the NLRA ${ }^{10}$ extend only to unions which have been certified by the Board. Although it is settled that cards do not enjoy those particular statutory privileges, it has not been entirely clear whether cards are subject to the statutory limitations placed upon elections by section 9 (c) (3) of the NLRA, which provides as follows:

No election shall be directed in any bargaining unit or any subdivision within which, in the preceding twelve-month period, a valid election shall have been held. . . .20

In 1947 Congress added this section to the NLRA and thus, by applying the twelve-month bar where the outcome of a Board election is conclusively for or against retention of a bargaining representative, expanded the Board's original rule, which created a bar only if the union had won the first election. ${ }^{21}$ In Brooks $v . N L R B,{ }^{22}$ the Supreme Court determined that the congressional purpose which motivated the enactment of section 9 (c) (3) was the achievement of stability in the area of labor relations. More specifically, the Court noted that Congress hoped to encourage responsibility in the electorate by according a degree of permanence to election results ${ }^{23}$ and to promote industrial peace by minimizing the unsettling effect of continuous elections. ${ }^{24}$ The Court indicated that this latter policy is especially significant where, as in Conren, rival unions were competing for recognition. ${ }^{25}$ Of course, where a union has won the election there is the additional policy of providing the winner with a period free from interference in which to attempt to carry out its mandate. ${ }^{2 b}$

Where a union has won an election, certification of a bargaining

\footnotetext{
${ }^{10}$ Added by 61 Stat. 144 (1947), as amended, 29 U.S.C. $\$ \S 158$ (b) (4) (B), (C) (1964).

${ }^{20}$ Added by 61 Stat. 144 (1947), as amended, 29 U.S.C. $\$ 159$ (c) (3) (1964).

${ }^{21}$ S. Rep. No. 105, 80th Cong., 1st Sess., pt. I, at 12, 25 (1947); id., pt. 2, at 11; H.R. REP. No. 245, 80th Cong., 1st Sess. 39 (1947); 93 Cong. REc. 3838 (1947) (remarks of Senator Taft); $i d$. at 3445 (remarks of Representative Lane); id. at 3447 (remarks of Representative Klein); id. at 3528 (remarks of Representative Powell); $i d$. at 6504 (remarks of Senator Murray). See generally Cushman, The Duration of Certifications by the National Labor Relations Board and the Doctrine of Administrative Stability, 45 Mich. L. REv. 1 (1946).

22348 U.S. 96 (1954), 35 B.U.L. REv. 300 (1955), 69 HARv. L. REv. 185 (1955).

${ }^{28} 348$ U.S. at 100; S. REP. No. 105, 80th Cong., 1st Sess., pt. 1, at 12 (1947).

24 348 U.S. at 100; 93 CoNG. REC. 3838 (1947) (remarks of Senator Taft).

25348 U.S. at 100 .

${ }^{28}$ Marjack Poultry, 136 N.L.R.B. 785 (1962); Rockwell Valves, Inc., 115 N.L.R.B. 236 (1956).
} 
representative has been held to preclude the creation of a representation question for one year unless the certified representative is unable or unwilling to assume its responsibilities. ${ }^{27}$ Prior to Conren, the issue of whether the one-year bar governed the use of cards when no union had been designated in the election had been evaluated only by trial examiners. ${ }^{28}$ While the respective analyses varied somewhat, each examiner had refused to accept a blanket application of section 9 (c) (3) as a justification for a refusal to bargain. In Ecko Prods. Co.29 the Board rejected the notion that labor stability was achieved by applying section 9 (c) (3) to authorization cards tendered in the election year. There, in the context of a recognitional strike, an employer unsuccessfully argued that section 9 (c) (3) provided an exemption from all union organizational activity' during the year following the employees' vote for no union. The Board stated that the controlling policy of industrial peace was advanced more effectively by recognition of bargaining representatives rather than by assuring a year of unimpeded operations for the employer. ${ }^{30}$ Hence, in the Board's view, the concern for permanance of elections appears to be subordinate to the establishment of effective collective bargaining machinery. However, Ecko Prods., at least with respect to recognitional picketing, was repudiated by Congress in its 1959 enactment of section $8(\mathrm{~b})(7)(B)$, which prohibits recognitional picketing within twelve months of an election. ${ }^{31}$

In his argument that section 9 (c) (3) relieved any duty to bargain on the basis of cards, the employer in Conren relied on the policy of industrial peace as set forth in Brooks. The court, in rejecting the employer's contention, grounded its holding on a very narrow interpretation of section 9 (c) (3). The court reasoned that the langnage and legislative history of section 9 (c) indicate that Congress was aware of several means for choosing a bargaining representative, but that section 9 (c) (3) in explicit terms covers only elections. Since, in the court's view, Congress had selected one method to implement its

\footnotetext{
${ }^{27}$ See Brooks v. NLRB, 348 U.S. 96, $98-99$ (1954); Lift Trucks, Inc., 75 N.L.R.B. 998 (1948); cf. Rocky Mountain Phosphates, Inc., 138 N.L.R.B. 292 (1962).

${ }^{28}$ See Strydel, Inc., 156 N.L.R.B. No. 114 (1966); Dow Chemical Co., I52 N.L.R.B. 1150, 1164-71 (1965); Majestic Lamp Mfg. Corp., 143 N.L.R.B. 180, 186-87 (1963).

20 117 N.L.R.B. 137 (1957).

${ }^{80} \mathrm{Id}$. at $143,144$.

${ }^{81}$ National Labor Relations Act $\$ 8(\mathrm{~b})(7)(B)$, added by 73 Stat. 544 (1959), as amended, 29 U.S.C. $\$ 158$ (b) (7) (B) (1964).
} 
policies, the court deemed itself powerless to extend the application of section 9 (c) (3) to other means. ${ }^{32}$ The dissenting opinion focused on the underlying purposes of section 9 (c) (3) and concluded that the policy of industrial peace dictated that cards be placed in the same category as elections for the purpose of the one-year bar of section 9 (c) (3)..$^{33}$

The majority opinion is disappointing because it fails to consider the impact of the decision upon the purpose of section 9 (c) (3). The seriousness of this omission is compounded by the reliance placed upon a statutory construction of doubtful validity. The language and legislative history of section 9 (c) could be reasonably interpreted to demonstrate that the drafters of theTaft-Hartley Act believed that elections would be the sole means utilized to select a bargaining agent. $^{34}$ In light of that legislative history, it is not surprising that section 9 (c) (3) expressly mentions only elections. Yet since judicial interpretation of section 9 has allowed other representation procedures besides elections, section 9 (c) (3) should likewise be expanded to encompass these additional forms. Furthermore, in adding that section to the NLRA, Congress determined that according a reasonable degree of permanence to the outcome of elections would best serve the interests of collective bargaining by rendering an election more meaningful as a medium for the reflection of employee desires. Moreover, section 9 (c) (3) is applicable whether the union wins or loses the election. Congressional policy to promote stability would apparently equally control the use of cards within the election year. Indeed, the permanence of election results is even more impaired when supervened by cards than by an untimely second election because of the informality of the card procedure with its concomitant absence of regulation. Clearly, the mandate of the Supreme Court that the results of a solemn and expensive Board election should be revoked by a procedure no less solemn ${ }^{35}$ is violated by this use of cards. Significantly, in the area of recoguitional picketing, Congress reaffirmed its desire to realize labor stability by strengthening the

32368 F.2d at 174 .

${ }^{33}$ Id. at 177 (dissenting opinion).

"See authorities cited note 21 supra. Compare National Labor Relations Act $\S 9$ (c), 49 Stat. 453 (1935), with National Labor Relations Act $\S 9$ (c) (1), (3), 61 Stat. 144 (1947). See generally Comment, 75 YALE L.J. 805, 820 (1966).

${ }^{35}$ Brooks v. NLRB, 348 U.S. 96, 99-100, $103-04$ (1954); 368 F.2d at 176.77 (dissenting opinion). 
electoral process in the enactment of section 8 (b) (7) (B). ${ }^{36}$ Arguably, the amendatory provisions of the Taft-Hartley and Landrum-Griffin Acts reflect a congressional desire that the encouragement of collective bargaining should be tempered by considerations of employee free choice and labor stability. However, the Conren case clearly demonstrates that the Board and the Seventh Circuit believe that the first step to establish labor stability must be the recognition of an organized bargaining representative. Thus, it is only after the selection of a bargaining representative that the policies of permanent election results may be expected to be given effective application to bar the use of authorization cards. It is because legislation in the area of labor relations involves sensitive policy judgments that the Supreme Court has stated that statutes should not be interpreted with "mutilating narrowness," 37 and it is arguable that the rationale employed by the Board and the Seventh Circuit in Conren encourages labor organization at the expense of other valid policies.

${ }^{36}$ National Labor Relations Act $\$ 8$ (b) (7) (B), added by 73 Stat. 544 (1959), 29 U.S.C. $\$ 158$ (b) (7) (B) (1964); Aaron, The Labor-Management Reporting and Disclosure Act of 1959: II, 73 HARv. L. REv. 1086, 1103-04 (1960); see note 31 supra and accompanying text.

${ }_{87}$ United States v. Hutcheson, 312 U.S. 219, 235 (1940). 